\title{
THE IMPLEMENTATIONOF PORTAL UNION CATALOG SERVER SULSELLIB BASED ON SENAYAN LIBRARY MANAGEMENT SYSTEMS (SLIMS)
}

\author{
A. Khaidir Akbar \\ Central Library of Universitas Islam Negeri Alauddin Makassar \\ Jl. H.M. Yasin Limpo No. 36 Samata Kab. Gowa, Sulawesi Selatan, \\ Indonesia \\ E-mail : a.khaidirakbar@gmail.com \\ Muhammad Azwar \\ Faculty of Adab and Humaniora,Universitas Islam Negeri Syarif \\ Hidayatullah Jakarta \\ Jl. Ir. H. Juanda, No. 95 Ciputat, Tangerang Selatan, Banten,Indonesia \\ 15419 \\ E-mail : muh.azwar@uinjkt.ac.id
}

\begin{abstract}
The research attempts to explain Portal Union Catalog Server (UCS) based on Senayan Library Management Systems (SLiMS) in South Sulawesi, Indonesia. Portal UCS becomes the media of technological information in developing cooperation among libraries in searching of thecollection in South Sulawesi, Indonesia. This research principally aims to know the implementation of that portal, the obstacles it deals with, and the hope of SLiMS Community on Portal UCS Sulsellib. This research is basically included as a descriptive research using aqualitative approach. As regards to informantsas the data sources of research, they are mainly somesuperintendentsand users of Portal UCS Sulsellib. Someresearch shows that the implementation ofPortal UCS Sulsellib can be very helpful forlibrary users in accessing information of collection in various libraries in South Sulawesi because it is only through one door of theportal webof UCS Sulsellib.SLiMS community uses the technic of Waterfall model adapted from System Development Life Cycle (SDLC). The stages of applying this portal are based on waterfall model that is planning, analysis, display design, promotion, implementation, andmaintenance. The hope is that this research can extensively upgrade the performance of Portal UCS Sulsellib so that it can be very helpful to explore acollection of informationto be more effective and efficient. Besides, it will beused as references to renew the unioncatalog system.
\end{abstract}

Keywords : Union Catalog Server;Portal UCS Sulsellib; Senayan Library Management Systems (SLiMS) 


\title{
A. Khaidir Akbar, Muhammad Azwar, the implementationof portal...
}

\begin{abstract}
ABSTRAK
Penelitian ini mencoba untuk memaparkan Portal Union Catalog Server (UCS) dengan berdasarkan aplikasi Senayan Library Management System (SLiMS) di Sulawesi Selatan, Indonesia. Portal ini menjadi media informasi teknologi untuk mengembangkan kerjasama antar perpustakaan dalam penelusuran koleksi. Penelitian ini pada intinya bertujuan untuk mengetahui bagaimana pengimplementasian portal tersebut, hambatan yang dihadapi, dan harapan dari Komunitas SLiMS pada Portal UCS Sulsellib. Penelitian ini merupakan penelitian deskriptif dengan menggunakan pendekatan kualitatif. Berkenaan dengan informan sebagai sumber utama data penelitian, mereka merupakan pengurus dan sekaligus pengguna dari Portal UCS Sulsellib. Hasil dari peneltian menunjukkan bahwa penerapan Portal UCS Sulsellib dapat sangat membantu pengguna perpustakaan dalam mengakses koleksi di berbagai perpustakaan di Provinsi Sulawesi Selatan karena hanya dengan melalui satu Portal UCS Sulsellib. Komunitas SLiMS menggunakan model Waterfall yang diadaptasi dari System Development Life Cycle (SDLC) dalam penerapannya yaitu perencanaan, analisis, desain tampilan, promosi, implementasi, dan pemeliharaan. Harapan untuk Portal UCS Sulsellib yang dipaparkan dalam penelitian ini adalah dapat meningkatkan kinerja Portal UCS Sulsellib secara ekstensif sehingga sangat membantu dalam mengeksplorasi koleksi informasi agar lebih efektif dan efisien. Selain itu, akan digunakan sebagai referensi untuk memperbarui sistem dari Portal UCS Sulsellib.
\end{abstract}

Kata Kunci: Server Katalog Induk; Portal UCS Sulsellib; Senayan Library Management System

\section{A. INTRODUCTION}

In line with the development of age, the system to search for information has been extremely advanced, so to look for information is not difficult at all forinformation seekers.Technology is continually developing to make human easier in doing their daily activities and in fulfilling their needs of information. It is because information has become their primary need which has to be fulfilled.

Government regulation of Republic of Indonesia No. 24, 2014 on the implementation of law No. 43, 2007 on Cooperation and Public Participation,Article 42 Paragraph (3) which generally explains that the cooperation as what it means in article (1) and improvement of service as 
what it means in article (2) is done by utilizing library network system based on the technology of information and communication ${ }^{1}$.

The use of technology in the field of thelibraryshould be applied to facilitate librarian or information seeker when they would like to find information. It simply means that technology bridges librarian and library. The importance of information in the age of technology like now places information as a determining point in almost every activity in society. In the field of business and economy, information is a precious commodity.

In exploring the collection of books in thelibrary, library users usually use catalog either manually or the one which is already based on technology like OPAC (Online Public Acces Catalog). However, if they onlyuse themanual catalog or even OPAC, they can only search for information in one library.Definitely, it would not be a problem if theycould find what they would like to look for. Nonetheless, if it was not the case, this would be a problem for them.

Hence, the system which is able to simultaneously utilize various catalogs is made to solve this problem. In a more specific meaning, it is a system which can show library users all of the collections from various libraries which are joined in that system. The access to find any information becomes wider because it is not only centralized in one library, but also in every library which is registered in such system. It is possible to do so by using catalog from each library and entering the database of that system.

The system which covers catalog fromall of thelibraries is called as Union Catalog. The union catalog is a combination or collection of some library catalogs showing theamountof collection which is available in each library to give information to library users in any libraries containing the collection they are looking for.

One of the union catalog developers in Indonesia is Senayan Library Management Systems(SLiMS) Community. SLiMS Community has the vision to unite all of thelibraries in Indonesia using SLiMS automation system application. Many union catalogs have been developed in accordance with the area where the community is located such as Jogjalib Portal UCS (http://ucs.jogjalib.net),Jatimlib Portal UCS (http://ucs.jatimlib.net), Primurlib Portal UCS (http://ucs.primurlib.net), and so forth. All union catalogs above use UCS based on SLiMS.

\footnotetext{
${ }^{1}$ Republik Indonesia, Undang-Undang RI Nomor 43 Tabun 2007 Tentang Perpustakaan (Jakarta: Tamita Utama, 2009).
} 


\section{A. Khaidir Akbar, Muhammad Azwar, the implementationof portal...}

In South Sulawesi, the union catalog has been developed, namely Portal UCS Sulsellibwhich address is http://ucs.sulsellib.net. This union catalog is expected to be able to accommodate all catalogs of bibliography from all libraries in South Sulawesi.

This research is closely related to previous research explaining the training of automation system based on Senayan Library Management Systems (SLiMS) for thestaff of Islamic school in SouthSulawesi. The research recommended the importance of paying close attention to the aspect of convenience in using such application of automation system both in function of theavailable menu and in serving module material of given training. The expectation is thatSLiMS application can be intensively used by most of thelibrarians in anIslamic school in implementing automation system in South Sulawesi.

According to R. and Srinivasaragavan ${ }^{2}$, the fundamental principle in creating a union catalog is the controlled harvesting of data of the broadest possible scope, with the aim of creating a concentrated information base and a qualitatively and quantitatively rich source of secondary documents (records). Then, to build Portal UCS Sulsellib is considered very important to unite all library catalogs based on SLiMS so that they can be connected to each other and make it easier for users in searching any information of collection because it is only done by utilizing one portal of theweb, namely http://ucs.sulsellib.net, which is harvesting all of the data from the libraries.

Portal UCS Sulsellib is still in a developing stage, so there are so many things to do to make it more developed. SLiMS Community is carrying out the renewal of such portal by developing some aspects, the same as Chand and Chauhan ${ }^{3}$, the development of a union catalogue is a continuous process, which needs consistent collaboration and participation from member libraries. It explains a union catalog is a sustainability thing.

From what has been elaborated above, the writer is highly interested in a research concerning with Portal UCS Sulsellib, with the title "The Implementation of Portal Union Catalog Server Based on Senayan Library Management Systems (SLiMS) in South Sulawesi, Indonesia".

\footnotetext{
${ }^{2}$ Prabu R. and S. Srinivasaragavan, "Bharathilibnet: An Online Union Catalogue Model for Bharathidasan University and Its Affiliated Colleges” 1, no. 4 (n.d.): 216-22.

${ }^{3}$ Prem Chand and Suresh K. Chauhan, "The Union Catalogue of Academic Libraries in India: An Initiative by INFLIBNET," Interlending \& Document Supply 36, no. 3 (August 15, 2008): 142-48, doi:10.1108/02641610810897854.
} 
Based on the problem of formulation, the purposes of this research areto know the implementation of Portal UCS Sulsellib carried out by SLiMS Community, to know the obstacles which SLiMS Community deals in applying Portal UCS Sulsellib, and to know the expectation of SLiMS Community as the developer of Portal UCS Sulsellib.

The research is highly expected to be able to give benefits to science in general and readers. The benefit which is expected to be actualized in this research istheoretically, to give more knowledge about thetechnology of information applied in the field of library, especially regarding the Sulsellib.net online union catalog. Practically, for the developer that, in this case, is SLiMS Community, they can use this research as areference to update the union catalog system.

\section{B. THEORETICAL REVIEW}

\section{The Definition of Catalog}

According to Tarullithe catalog has always been the same, reliable tool that first appeared in print form in 1595 at the Leiden University Library. However, libraries began using catalogs as early as the 800 s, organizing books from their collection into categories and genres.

\section{The Union Catalog}

Azwar ${ }^{5}$ says thatthe union catalog means to unite or unifycatalog from a number of libraries. Users only have to see one website of catalog named as union catalog portal. By using this portal, users can explore catalog from various libraries.Muin ${ }^{6}$ states the same meaning thatunion catalog in English is normally called Union Catalogue Server (UCS). Its display on the internetis frequently called as Portal Union Catalogue Server because it integrates and connects several websites of OPAC.

A well-maintained union catalog will serve as a discovery tool for end-users; therefore, maintaining the currency of union catalogs is essential. Since libraries are growing organisms, new documents are

\footnotetext{
${ }^{4}$ Laurel Tarulli, The Library Catalogue as Social Space (Santa Barbara: Libraries Unlimited, 2012). 2012

${ }^{5}$ Muhammad Azwar, "Membangun Sistem Otomasi Perpustakaan dengan Senayan Library Management System (SLiMS)," Jurnal Ilmu Perpustakaan \& Informasi KHIZANAH AL-HIKMAH 1, no. 1 (2014): 19-33.

${ }^{6}$ Muh. Azwar Muin, Information Literacy Skills: Strategi Penelusuran Informasi Online (Makassar: Alauddin University, 2014).
} 


\section{A. Khaidir Akbar, Muhammad Azwar, the implementationof portal...}

constantly being added. The visibility of such collections will improve if OPACs are built and made available to end-users independent of their geographical location. According toAlam and Pandey ${ }^{7}$, the union catalog is a discovery tool to make it easier for users in finding the materials they are looking for by showing where geographically the nearest libraries are.

On the basis of the definition above, it can be inferred that union catalog is a collection of severalbibliographic catalogs from a number of libraries which are integrated into one system which its purpose is to make users easier in searching materials. Azwar ${ }^{8}$ describes this union catalog appears as a form of cooperation among libraries. It can support and complete the collections among them. One cannot become a perfect library which possesses a complete collection only by existing alone. Therefore, cooperation is a necessity. The collection of several libraries is compiled into one, so it is to be immense or complete.

\section{The Online Union Catalog}

Machovec ${ }^{9}$ statesthat the online union catalog allows users to view library holdings and circulate information with a single query of the central database. The union catalog will also allow patrons to request items from any of the participating libraries and have them delivered to a nearby local library. This online union catalog only refers to any registered libraries in one union catalog network and it will present the nearest libraries to users looking for references.

Henriyadi ${ }^{10}$ made two methods in developing online union catalog whichis can be applied:

\section{a. Centralized System}

It is a library system server made to be a host, whereas amember of thenetwork is a knot of the data supplier. On the main server, the process of verification and data integration is done before it is sent to users. The benefit of

\footnotetext{
${ }^{7} \mathrm{Md}$. Nurul Alam and Pragya Pandey, "SpaceCat: An Online Union Catalogue for Space Science Serials in India," Interlending \& Document Supply 38, no. 4 (November 2010): 200-209, doi:10.1108/02641611011094329.

${ }^{8}$ Muin, Information Literacy Skills : Strategi Penelusuran Informasi Online.

'George S. Machovec, "Prospector: A Regional Union Catalog in Colorado \& Wyoming," Information Intelligence Online Libraries and Microcomputers 17, no. 6 (1999): 1-5. ${ }^{10}$ Henriyadi, "Pengembangan Katalog Induk Online Perpustakaan Lingkup Badan Litbang Pertanian," Perpustakaan Pertanian 18, no. 2 (2009): 56-62.
} 
thecentralizedsystem is that the development processbecomes easier, the infrastructure of each knotdoes not need to be high and on the knot, the only thing is needed is a manager for data entry. The drawback of thecentralized system model is that the main task is concentrated on server manager while server infrastructure and connection must be good and strong, as well as the need to standardize application and structure of thedatabase.

\section{b. Scattered system}

It is that each library operates their own servers, whereas the main server is only for data harvesting both manually and automaticallyfor certain period of time by using aframework of Open Archive Initiative (OAI). The benefit of thescattered system is that we do not need standardization of document format, namely Extended markup language (XML), and the burden of thetask is spread out on each knot. The weakness isthe need fora special application which is set up in the central server to collect and harvest data, while detail information and complete document are available in each knot server.

\section{The Function of Online Union Catalog}

The online union catalog does not only make the process of browsing information towards various library catalogs through one website portal easier, it also has additional functions, namely:

\section{a. Simplify the Copy Cataloguing}

$\mathrm{KaO}^{11}$ says thatcopy cataloging is a process of retainingcatalog information which has been done before and implements it into local use.It does not only preserve time, it can also preserve money and the work of library staffs based on speed and prime quality. Furthermore, Syukur ${ }^{12}$ appends thatby using the automatic system application such as SLiMS, the copy cataloging can be done with Peer to peer (P2P Service) and protocol Z39.50. The P2P service means that it can undergo

\footnotetext{
${ }^{11}$ M. L. Kao, Cataloging and Classification for Library Technicians (New York: Haworth Press, 2001).

12Abdul Syukur, Taufiq Mathar, and Muhammad Azwar, "Pemanfaatan Fitur Z39.50 Pada SLiMS (Studi Kasus Di Perpustakaan Fakultas Adab Dan Humaniora UIN Alauddin)," Jurnal Ilmu Perpustakaan \& Informasi KHIZ ANAH AL-HIKMAH 4, no. 1 (2016): 45-56.
} 


\section{A. Khaidir Akbar, Muhammad Azwar, the implementationof portal...}

copy cataloging from users that have the same application, SLiMS for an example. Protocol Z39.50 appears as an International server-client protocol (ISO Z39.50) which is to browse the information center among the interconnected computers.

b. Support the bibliographic control

According toHermawan ${ }^{13}$,the bibliographic control is the effort in developing and preserving a listing system for all inventorial forms, which is not only for the established but also for the printed and non-printed that support information and knowledge. Such control is mandatory, so information can be used at an optimal level.

Suwarno ${ }^{14}$ notes that the development of all aspects, science and technology, social science, humanities, and all daily aspects, are relying on the well-managed knowledge and information, so they can be easily and fastly accessed if required.

\section{c. Inter-Library Loan}

According to Kochtanek and Matthews ${ }^{15}$, the union catalog has a prominent role in inter-library loan occurrence. By accessing the online union catalog, the library user may easily identify the whereabouts of the information required and how to retain it.According to Suwarno and Miswan ${ }^{16}$, the union catalog is also further developed in order to construct the library borrow-delivery service.

\section{Portal UCS Sulsellib}

SliMS Community ${ }^{17}$ reports that Portal UCS Sulsellib is a common online portal catalog for libraries in South Sulawesi. Portal UCS Sulsellib consists of apublic library, university library, school

\footnotetext{
${ }^{13}$ Hermawan, Fungsi Katalog Induk Dalam Memenubi Kebutuban Informasi Stakebolders, 2016, https://library.uns.ac.id/fungsi-katalog-induk-dalam-memenuhi-kebutuhan-informasistakeholders/.

${ }^{14}$ Wiji Suwarno, Organisasi Informasi Perpustakaan (Pendekatan Teori Dan Praktik) (Jakarta: Raja Grafindo Persada, 2016).

${ }^{15}$ Thomas R. Kochtanek and Joseph R. Matthews, Library Information Systems : From Library Automation to Distributed Information Access Solutions (United States of America: Libraries Unlimited, 2002).

${ }^{16}$ Wiji Suwarno and Miswan, Jaringan Kerja Sama Perpustakaan Dan Informasi (Tangerang Selatan: Universitas Terbuka, 2014).

${ }^{17}$ Komunitas SLiMS, About Us, 2015, http://ucs.sulsellib.net/index.php?p=libinfo.
} 
library, LSM library, book garden, and so forth.Portal UCS Sulsellibhas its previous one called UCS Makassarlib and its address washttp://makassarlib.net, but because it only coveredlibraries in Makassar, sothe area it covered was limited. Therefore,UCS Sulsellib is developed as a continuation of UCS Makassarlib.

This portal is a supporter of developing libraries in South Sulawesi, especially in cooperation among libraries in the field of information technology. A big system should be well organizedso that it can run as it should be. Sullsellib Portal UCS is not an exception in this case. Its developer that is SLiMS Community must excellently organize it. It is a duty that in organizing a system, it should be continually done.

Portal UCS Sulsellib as a big system that covers one province of South Sulawesi should be balanced with a big resource as well like in renting domain and hosting. In addition, human resource is needed to organize that portal including upgrading, restoring any possible damage and developing that system.

According to SLiMS Community ${ }^{18}$ These are benefits of Portal UCS Sulsellib:

a. To make it easier in searching through collections because of just by one portal.

b. To help or facilitate users in building library database in the place where they work, such as P2P Service (taking database which is already in the portal to be inserted to local database) which is known as copy cataloging, or just to know notation of clarification, headline, and subject, or just to monitor development of collection.

\section{Implementation of Online Union Catalog}

To talk about implementation, there must be stages to be done soa system can run as it should be. According to $\mathrm{Ali}^{19}$, theapplication is to practice and to set up. By such definition, it can be concluded that application is an action which is correctly done either individually or communally to reach the planned goal.

The stages to apply a system of online union catalog is by using Linear Sequential Model or well known as Waterfall Model adapted from System Development Life Cycle (SDLC) because its design looks like a waterfall. This model was introduced in the first

${ }^{18}$ Komunitas SLiMS, About Us, 2015.

${ }^{19}$ Lukman Ali, Kamus Besar Bahasa Indonesia (Jakarta: Balai Pustaka, 1995). 


\section{A. Khaidir Akbar, Muhammad Azwar, the implementationof portal...}

time by Winston Royce in 1970. Even though it is an old theory, but it is still effective to be used in theimplementation of union catalog system.

Actually, this Waterfall Model is frequently used in software engineering, but that model can also be used in the implementation of online union catalog so that it can be a reference in this research.

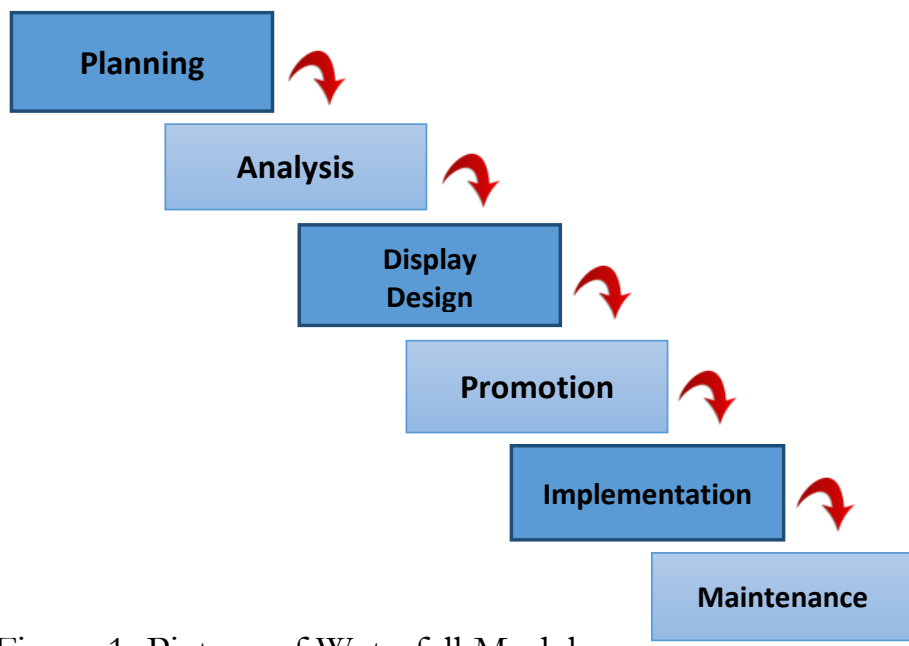

Figure 1: Picture of Waterfall Model

\section{a. Planning}

This stage is a process of identification regarding the condition of libraries which will later be joined in online catalog system, whether the owner of thelibrary will be interested if his library becomes part of that union catalog.

b. Analysis

This stage is done after planning process is completed, so then the study of theadvisability of union catalog system will be done, whether it will be suitable or it will have errors impeding the work system.

c. Display Design

This stage is a design process of thetemplate from online union catalog OPAC. In this process, the attention to theaesthetic value of OPAC display is necessary and it is very easy to understand its usagefor alibrarian.

\section{d. Promotion}


This stage is product promotion to consumers, which are all libraries in South Sulawesi, either public library, university, school, or book garden.

\section{e. Implementation}

This stage is a process of implementation of the union catalog. This is the main process of the online union catalog, where its utilizing has already started to be done by thelibrarian.

\section{f. Maintenance}

Henriyadi $^{20}$ says that maintenance is a stage after the online union catalog has been already used by thelibrarian. In this stage, the maintenance will be very often carried out, such as payment of domain and hosting, where the union catalog is registered.

If those five stages have already been undertaken, the implementation of online union catalog has been in accordance withapplied procedure. Even though the process of maintenance is completed, it does not necessarily end those processes, but rather they must becontinually done.In other words, we still need to do planning to further develop the system, theprocess of analysis to analyze the weaknesses of the system, design to make it more interesting and easier to understand, and to implement the important things to develop the online union catalog.

\section{METHODOLOGY}

The method of this research is thequalitative approach, which is a descriptive research. A qualitative approach is a research that produces ananalysiswhich is not based on statistical analysis procedure or any other quantification way. The data sources can be divided into two parts, namely primary and secondary data. The primary data are obtained by doing interview process with some of SLiMS Community members as thedeveloper of Portal UCS Sulsellib. The secondary data are literature, journal, article, and reliable website.The subject of this research is some of Sulsellib SLiMS Community members who are believable to be as informants, like Ahmad Adil, S.Sos (a member of Sulsellib SLiMS community, lecturer in science of library in UIN Alauddin, and librarian at the library of FKM UNHAS), Taufiq Mathar, S.Pd., M.LIS (member of Sulsellib

${ }^{20}$ Henriyadi, "Pengembangan Katalog Induk Online Perpustakaan Lingkup Badan Litbang Pertanian." 


\section{A. Khaidir Akbar, Muhammad Azwar, the implementationof portal...}

SLiMSCommunity and lecturer in science of library), and Muh. Azwar, M.Hum (coordinator of Sulselib SLiMS community and a lecturer in library science).

The techniques of data collection to obtain information to support this research are observation, interview, and documentation.After the data are collected, we undergo reduction of raw data of which are selected and simplified and its information is taken. The information is presented in writing based on factual cases which are interrelated.The researcher observes Portal UCS Sulsellib directly through http://ucs.sulsellib.net/

Display data are used as a tool to understand whattheyactually are. Then, the conclusion is inferred from the data based on the data analysis that has already been done.The technique of testing of data validity is obtained through deep observing activities, improving exertion, triangulation, and analysis of thenegative case, using reference materials and holding membercheck.

\section{RESULT AND DISCUSSION}

\section{Implementation of Portal UCS Sulsellib}

A common union catalog is a place for libraries in giving information that those libraries have bibliographic collection needed by users. Portal UCS Sulsellib is an example of common union catalog which is online and functions as adissemination tool that provides information to users, especially users in South Sulawesi.

The method used in applying this Portal UCS Sulsellibis based on System Development Life Cycle (SDLC), which is a process to understand how a system of information can support planning, development, and utilization of thesystem. There are several models which are developed on the basis of SDLC and one of them is Linear Sequential model, but it is better known as the waterfall model. In the implementation of Portal UCS Sulsellib, the waterfall model is used to seethe process of implementation in South Sulawesi. 


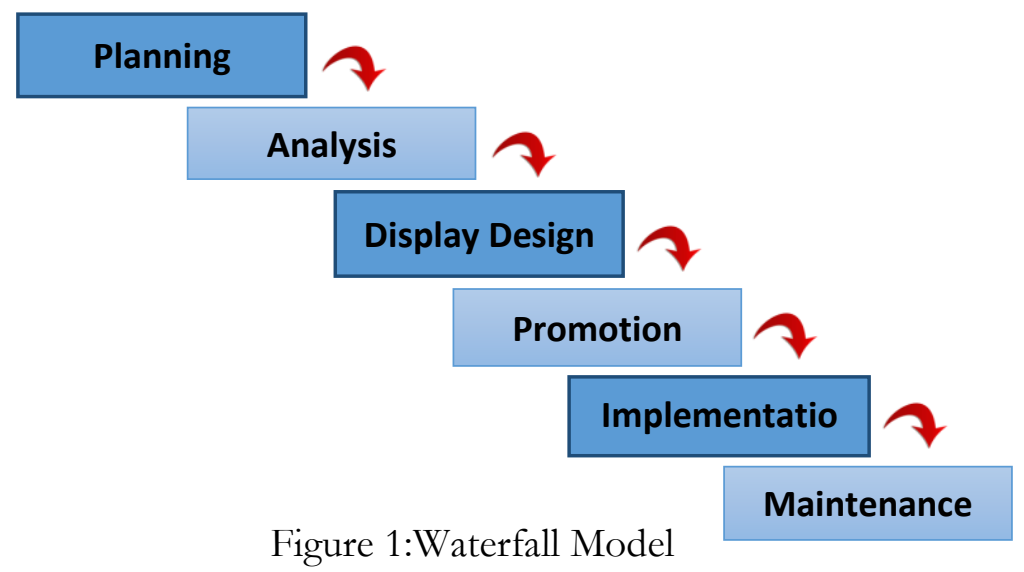

\section{a. Planning}

In this stage, SLiMS Community plans to extend the scope of Portal UCS Makassarlib. Thus, it is changed to be Portal UCS Sulsellib so that it can accommodate catalogs from various libraries outside Makassar.

Portal UCS Sulsellib is a metamorphosis of Portal UCS Makassarlib which has the same purpose with a different scope and this is why Portal UCS Sulsellib is created, that is to accommodate all libraries in South Sulawesi.In addition, maintenance of online union Portal catalog is easier to use because it can be accessed only by one portal. It will be more difficult to organize more than one portal. The search of library materials will be more effective if it is only through one portal. It means that only by accessing one portal on theinternet, it is enough to find needed materials.

b. Analysis

This stage is an analysis of system from Portal UCS Sulsellib that is to know whether it is sufficient to fulfill library need in uniting catalogs in one system. Apart from analyzing library needs, SLiMS Community also analyzes weaknesses in that portal, so it latercan berestored and renewed.

c. Display Design

In this stage, SLiMS Community makes interface display design of Portal UCS Sulsellib, where this portal display should be User-Friendlyandeasy to use by users. Display design of this portal gives emphasis on function than aesthetic value. However, it does not necessarily mean that it ignores the aesthetics of portal display at all. 


\section{A. Khaidir Akbar, Muhammad Azwar, the implementationof portal...}

Even though this portal interface display design is not prioritized, but SLiMS Community still consider the aesthetic value so that users do not feel bored when they access portal.

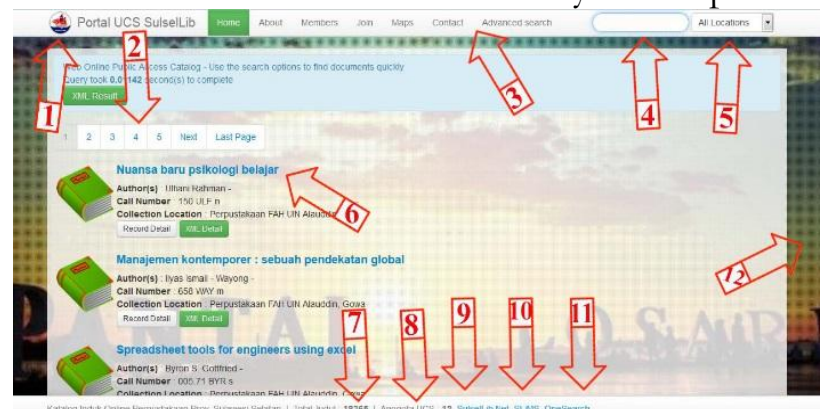

Figure 2 : Portal UCS Sulsellib Interface

(source: $\underline{\text { http://ucs.sulsellib.net/index.php) }}$

These are the explanations of the above picture: (1) Logo of Portal UCS Sulsellib, (2) Page per page, (3) Sub Menu of Portal UCS Sulsellib, (4) Search box, (5) List of library location, (6) List of bibliography which has been already indexed, (7) Amount of titles of bibliography which has been indexed, (8) Amount of Portal UCS Sulsellib member, (9) Link to Sulsellib website, (10) Link to SLiMS website, (11) Link to Indonesia One Search (IOS) website, and (12) Two pictures asbackground, which automatically changes every few seconds.

\section{d. Promotion}

SLiMS Community promotes Portal UCS Sulsellib in several media and opportunities, for example by using Facebook. Through Makassar SLiMSgroup, the promotion of this portal is introduced to the group members.

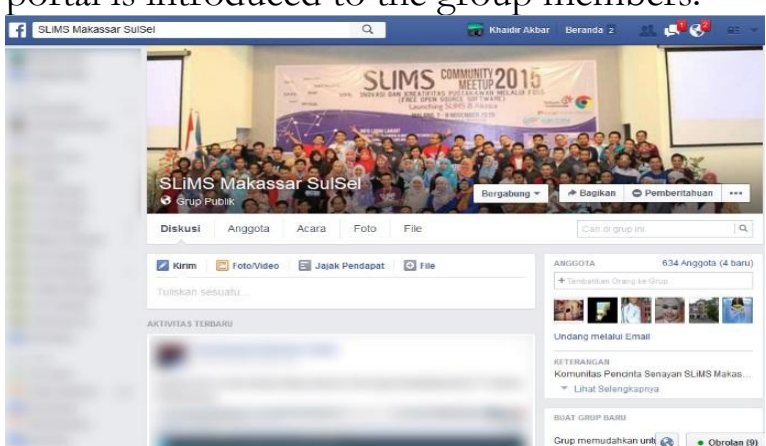

Figure 3: Sulsel Makassar SLiMS Group on Facebook (source: http://www.facebook.com/groups/217256554997567?refid=27) 
As the biggest social media in the world, Facebook becomes the main choice of SLiMS Community to introduce Portal UCS Sulsellib. Besides, the people who are eager to know more about this portal can directly ask the group.

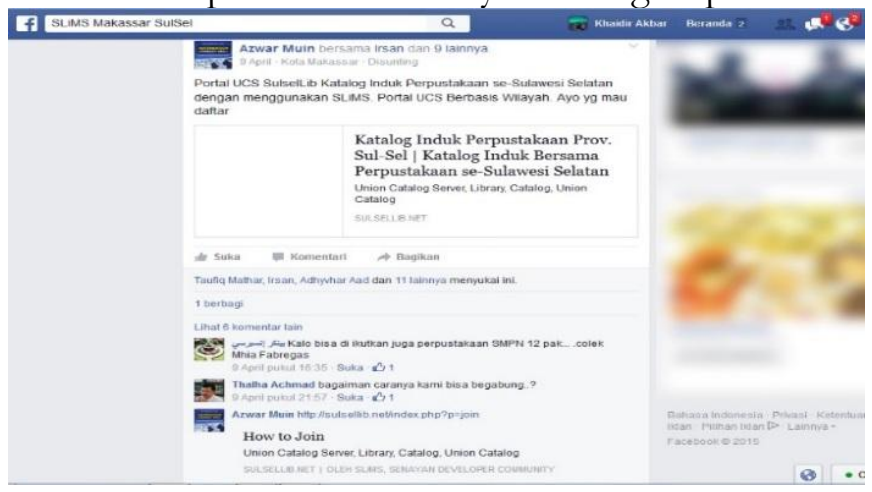

Figure 4: Promotion in Group of Facebook (Social Media) (source: http://www.facebook.com/groups/217256554997567?refid=27)

Besides Facebook, SLiMS Community also does promotion using the website of SulsellibSLiMSCommunity, which its web address is, http://www.sulsellib.net/. The website containsarticles about library and literature. This website also contains areport of activities done by SLiMSCommunitythroughout South Sulawesi.

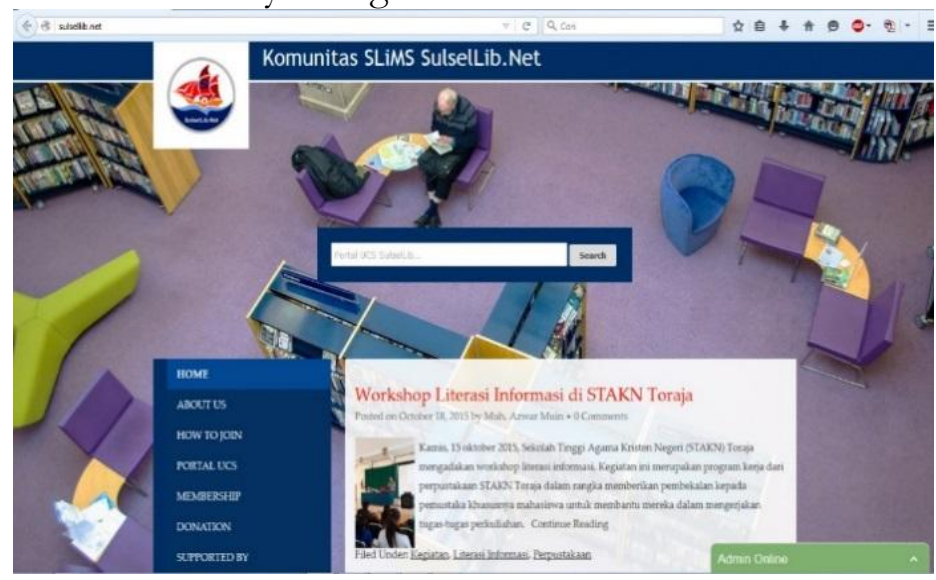

Figure 5: Sulsellib.net $W$ ebsite

(Sumber: http://www.sulsellib.net) 
An effective promotion activity which has a significant impact is when we do training of automation system in regions.

e. Implementation

This stage is the main point of the implementation of Portal UCS Sulsellib, where the location has already beenknown by society by the way of socialization done by SLiMS Community in regions.

The efforts of SLiMSCommunity to apply Portal UCS Sulsellib in South Sulawesi areby means of socialization and training done in regions, and by giving information about the union catalog portal in social media and website.

The training which is carried out by SLiMSCommunity isabout the way of using that Portal UCS Sulsellib, like in search of abook.

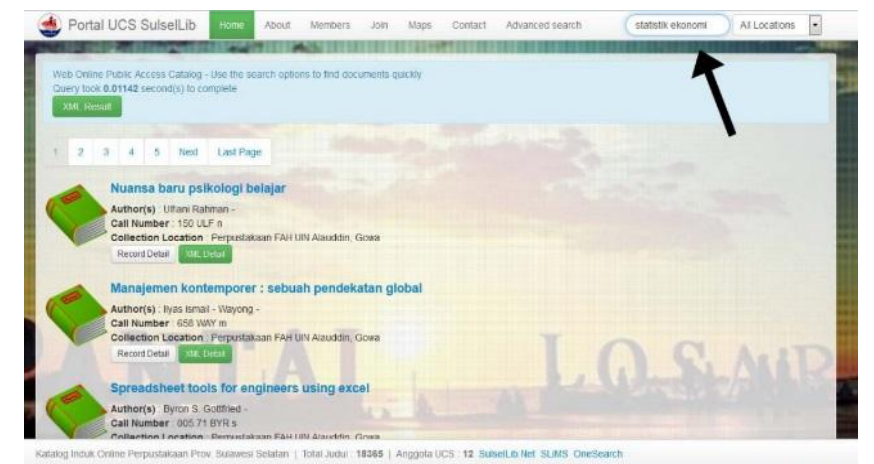

Figure 6: Book Search

(Sumber: http://www.ucs.sulsellib.net)

Just by typing the keywordof book title on thesearch box, and pressing the enter button, the result of thesearch will appear like in the following picture.

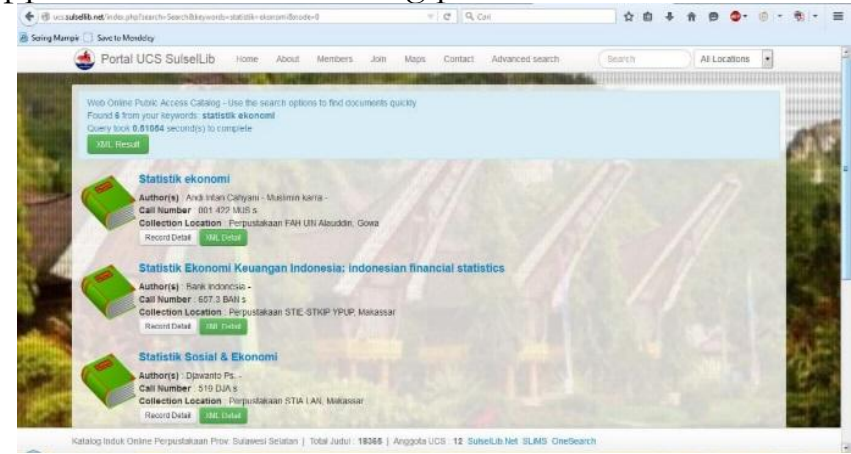

Figure 7: Result of Book Search

(Sumber: http://www.ucs.sulsellib.net) 
The result of thesearch of thebook appears on the first list and a brief description of abibliographyof thebook appears, such as thename of theauthor, call number and the location of the book.

This training receives a big appreciation from participants andthey are even very enthusiastic to join thetraining. By this training, the libraries in theregion are invited to join Portal UCS Sulsellib. So, besides carrying out the training of the way to use Portal UCS Sulsellib, the participants who are librarians asked to register their libraries as members of Portal UCS Sulsellib.

Up to now, SLiMS Community is still continually doing socialization either by training or by social media. Many libraries are joined and most of them are from Makassar.

\section{f. Maintenance}

In this stage, SLiMSCommunity starts to perform maintenance, such as continuous lease payment of domain and hosting in order that Portal UCS Sulsellib can still be accessed by users andto add hosting capacity when the number of thedatabase has reached the limit and to perform backup source code and database. In addition,the checking of thesystem is periodically carried out to find bugs or errors in the system and then to fix it, as well as contact the hosting provider when the server is paralyzed.

\section{The difficulties experienced by SLiMS Community in the implementation of Portal UCS Sulsellib}

Some of thebarriers faced by SLiMS community in the implementation of portal UCS Sulsellib :

\section{a. Human resources}

The lack of human resources to manage Portal UCS Sulsellib sometimes causes troubles to this portal due to thebustle of each of SLiMS Community member. Some administrators are lecturers and librarians.

\section{b. Management fund}

The next trouble is the lack of fund. SLiMS Community is an independent community which is not under the government so that the income fund only comes from adonationby people who care about SLiMS Community and Portal UCS Sulsellib. 


\section{c. Structure of organization has not been applied yet}

Structure of organization is a unit of work in one organization. It shows the main task and function of each member of anorganization based on his or her position.

SLiMS Community has not applied an organizational structure, so there is a lack of coordination among members. This situation causes the development process of Portal UCS Sulsellibto slow down and the implementation process to all regions in South Sulawesihas not spread out. It also causes the lack of development of Portal UCS Sulsellib.

d. Lack of Support from Government in South Sulawesi

To be more flexible in the implementation ofPortal UCS Sulsellibto regions, we need cooperation and coordination with provincial government and the local area with the library in that area. However, there has been, in fact, no cooperation carried out by agency and institution, so the implementation of this portal does not receive full support from the government.

\section{The expectation of SLiMS community to Portal UCS} Sulsellib in the future

In the previous discussion, the researcher has answered the first and the second problem formulation; those are the implementation of Portal UCS Sulsellib, and hindrances experienced by SLiMS Community in the implementation of anonline union catalog. In this part, the hopes of SLiMS Community for Portal UCS Sulsellib will be statedas follows:

a. SLiMS Community Member must grow and be more effective

SLiMS community is not fully active in developing Portal UCS Sulsellib because each of the members has his or her own activities.

b. Development of Portal UCS Sulsellib is Supported by Government

Lack of support from theprovincial and local government makes the development of Sulsellib Portal UCS grows slowlyand it is only to undergo promotion and normal training. With the cooperation and coordination from thegovernment, it is expected to be able to jointly develop Portal UCS Sulsellib so that the portal can be well known and utilized by all levels of society; especially those who are in South Sulawesi. 


\section{c. South Sulawesi Society can use Portal UCS Sulsellib}

The use of Portal UCS Sulsellib by Society in South Sulawesi is still low. It isindicated many people are still not familiar with the online union catalog.

\section{E. CONCLUSION}

After undertaking research about the implementation of Portal Union Catalog Server (UCS), the researcher infers a few points, Portal UCS Sulsellib has been applied as means of information that can be used by Society in South Sulawesi to find thebibliographic collection. The implementation which has already been done by SLiMS Community is properly based onWaterfall Model, which is planning, analysis, display design, promotion, implementation, and maintenance. There are some obstacles experienced by SLiMS Community in applying Portal UCS Sulsellib, those arehuman resources, management fund, lack of structure of theorganization, and lack of support from thegovernment.The expectations of SLiMS Community for Portal UCS Sulsellibis that members of SLiMS Community can continually grow and more active, the development of Portal UCS Sulsellib can get support from the provincial government in South Sulawesi, and society in South Sulawesi can optimally use the Portal UCS Sulsellib.

Here is the suggestion from the researchers regarding Portal UCS Sulsellib. In the development of Portal UCS Sulsellib, it needs two parties working together, which are, in this case, SLiMS Community and provincial government of South Sulawesi, to develop the portal, where the provincial government suggests to every local government to do socialization and training regarding Portal UCS Sulsellib and recommend every local library to join Portal UCS Sulsellib. With the merging of all local libraries in South Sulawesi, the database will also grow in that portal system, so society can easily and fastlyfind bibliographic collections.

\section{REFERENCES}

Alam, Md. Nurul, and Pragya Pandey. "SpaceCat: An Online Union Catalogue for Space Science Serials in India." Interlending \& Document Supply 38, no. 4 (November 2010): 200-209. doi:10.1108/02641611011094329.

Ali, Lukman. Kamus Besar Bahasa Indonesi. Jakarta: Balai Pustaka, 1995. Azwar, Muhammad. "Membangun Sistem Otomasi Perpustakaan dengan Senayan Library Management System (SLiMS)." Jurnal Ilmu 
A. Khaidir Akbar, Muhammad Azwar, the implementationof portal...

Perpustakaan \& Informasi KHIZANAH AL-HIKMAH 1, no. 1 (2014): 19-33.

Henriyadi. "Pengembangan Katalog Induk Online Perpustakaan Lingkup Badan Litbang Pertanian." Perpustakaan Pertanian 18, no. 2 (2009): $56-62$.

Hermawan. Fungsi Katalog Induk Dalam Memenubi Kebutuban Informasi Stakeholders, 2016. https://library.uns.ac.id/fungsi-katalog-indukdalam-memenuhi-kebutuhan-informasi-stakeholders/.

Kao, M. L. Cataloging and Classification for Library Technicians. New York: Haworth Press, 2001.

Kochtanek, Thomas R., and Joseph R. Matthews. Library Information Systems: From Library Automation to Distributed Information Access Solutions. United States of America: Libraries Unlimited, 2002.

Laurel Tarulli. The Library Catalogue as Social Space. Santa Barbara: Libraries Unlimited, 2012.

Machovec, George S. "Prospector: A Regional Union Catalog in Colorado \& Wyoming." Information Intelligence Online Libraries and Microcomputers 17, no. 6 (1999): 1-5.

Muin, Muh. Azwar. Information Literacy Skills : Strategi Penelusuran Informasi Online. Makassar: Alauddin University, 2014.

Prabu R., and S. Srinivasaragavan. "Bharathilibnet: An Online Union Catalogue Model for Bharathidasan University and Its Affiliated Colleges" 1, no. 4 (n.d.): 216-22.

Prem Chand, and Suresh K. Chauhan. "The Union Catalogue of Academic Libraries in India: An Initiative by INFLIBNET." Interlending \& Document Supply 36, no. 3 (August 15, 2008): 14248. doi:10.1108/02641610810897854.

Republik Indonesia. Undang-Undang RI Nomor 43 Tahun 2007 Tentang Perpustakaan. Jakarta: Tamita Utama, 2009.

SLiMS, Komunitas. About Us, 2015. http://ucs.sulsellib.net/index.php?p=libinfo. . About Us, 2015.

Suwarno, Wiji. Organisasi Informasi Perpustakaan Pendekatan Teori Dan Praktik). Jakarta: Raja Grafindo Persada, 2016.

Suwarno, Wiji, and Miswan. Jaringan Kerja Sama Perpustakaan Dan Informasi. Tangerang Selatan: Universitas Terbuka, 2014.

Syukur, Abdul, Taufiq Mathar, and Muhammad Azwar. "Pemanfaatan Fitur Z39.50 Pada SLiMS (Studi Kasus Di Perpustakaan Fakultas Adab Dan Humaniora UIN Alauddin)." Jurnal Ilmu Perpustakaan \& Informasi KHIZANAH AL-HIKMAH 4, no. 1 (2016): 45-56. 